\title{
Study on the relationship between lineaments and borehole specific capacity in a fractured and karstified limestone area in Vietnam
}

\author{
V. T. Tam · F. De Smedt • O. Batelaan - A. Dassargues
}

\begin{abstract}
For a karstified limestone area in NW Vietnam, the relationship between the distribution of lineaments and borehole specific capacity is determined, resulting in the conclusion that not only the borehole geomorphological-hydrogeological position but also the lineament distribution influences the specific capacity.

No significant spatial well yield patterns are evident in this highly fractured-karstified region. The supposition is that lineaments caused by geotectonic activities affect the local variability in borehole specific capacity. Sixteen pumping tests in conjunction with a comprehensive lineament analysis are used to prove this relationship. The boreholes and lineaments are classified into two groups according to their similarity in geomorphological-hydrogeological features. Lineaments tend to be less detectable in discharge areas (lowland, wide and flat valleys) in contrast to the high density in recharge areas (highland narrow-mountainous ravines). In addition, the presence of a stream network in the former can act as a recharge source to the underlain karstic groundwater system. Con-
\end{abstract}

Received: 27 January 2003 / Accepted: 18 February 2004

Published online: 9 July 2004

(C) Springer-Verlag 2004

F. De Smedt · O. Batelaan (

Department of Hydrology and Hydraulic Engineering,

Vrije Universiteit Brussel,

Pleinlaan 2, 1050 Brussels, Belgium

e-mail: batelaan@vub.ac.be

Tel.: +32-2-6293039

Fax: +32-2-6293022

V. T. Tam

Research Institute of Geology and Mineral Resources,

Ministry of Natural Resources and Environment,

Km 9 Nguyen Trai Street, Thanh Xuan, Hanoi, Vietnam

A. Dassargues

Département Géoressources,

Géotechnologies et Matériaux de Construction (GEOMAC),

Université de Liège,

B.52 Sart-Tilman, 4000 Liege, Belgium

Present address:

A. Dassargues, Hydrogeology and Engineering Geology,

Department of Geography-Geology,

K. U. Leuven,

Redingenstraat 16, 3000 Leuven, Belgium sequently, boreholes that are in the discharge areas with a lower density of lineaments often produce high yield. For recharge areas with a high density of lineaments, a good correlation is found between lineament density and borehole specific capacity.

Résumé La relation entre la distribution des linéaments et le rendement des puits est déterminée pour une région dans le nord ouest du Vietnam composée de calcaires karstiques. La conclusion qui résulte de l'analyse de cette relation est que la distribution des linéaments ainsi que leur niveau local d'érosion affectent le rendement des puits. Aucune tendance n'a été observée dans la distribution spatiale des puits selon leur rendement au sein de cette région karstique grandement fracturée. On suppose que les linéaments produits par l'activité géotectonique ont une influence sur la variabilité locale du rendement des puits. Les résultats de seize essais de pompage et une analyse complète des linéaments sont utilisés pour établir la relation. Les puits et les linéaments sont classés en deux groupes selon la similarité de leur caractéristiques géomorphologiques et hydrogéologiques. Les linéaments sont plus difficilement repérables dans les grandes vallées plates que dans les étroites vallées de montagne, qui présentent une densité élevée de linéaments. De plus, la présence de rivières dans les premières peut contribuer à la recharge du système d'écoulement souterrain karstique sous-jacent. Par conséquent, les puits situés dans les régions à faible densité en linéaments, mais qui se trouvent près de linéaments à niveau local d'érosion élevé présentent souvent un rendement élevé. Dans les vallées étroites ayant une grande densité de linéaments, il y a généralement une corrélation élevée entre la densité des linéaments et le rendement des puits.

Resumen El resultado ha sido la conclusión de que tanto la distribución de lineamientos como el nivel base local de erosión, i. e. la red de arroyos, influyen el rendimiento de los pozos. No hay ningún patrón evidente significativo de rendimiento de pozos según parámetros espaciales en esta región altamente karstificada y fracturada. La suposición es que los lineamientos causados por actividad geotectónica afectan la variabilidad local de rendimiento de los pozos. Se han utilizado dieciséis pruebas de bombeo en conjunción con un análisis de lineamientos amplio para descubrir la relación. Los pozos y lineamientos se 
han clasificado en dos grupos de acuerdo con sus similitudes en rasgos geomorfológicos-hidrogeológicos. Se tiende a detectar menos lineamientos en valles anchos y planos en contraste con la alta densidad en áreas de valles montańosos angostos. Adicionalmente, la presencia de una red de arroyos en estos últimos puede actuar como fuente de recarga del sistema de aguas subterráneas kárstico subyacente. En consecuencia, los pozos que se encuentran en el área con una menor densidad de lineamientos pero cercanos a un nivel local base de erosión frecuentemente tienen un rendimiento alto. En el caso de los valles angostos con una alta densidad de lineamientos, se ha encontrado una correlación alta entre densidad de lineamientos y rendimiento de pozos.

Keywords Vietnam - Karst - Carbonate rocks · Lineament $\cdot$ Groundwater exploration

\section{Introduction}

In areas where the bedrock has a low primary porosity and hydraulic conductivity, groundwater resides mainly in fractures or fissured zones, known as secondary porosity. Topographic maps, aerial photographs, and various types of satellite sensor imagery have been used to map lineaments that are often presumably interpreted as surface manifestations of fractured and possibly transmissive zones in an almost impermeable rock mass. Many attempts to quantify groundwater resources in hard rocks have been based on the mapping of these inferred transmissive fracture zones (Lattman and Parizek 1964; Mabee et al. 1994). However, results from studies of the correlation between mapped lineaments and borehole specific capacities have been ambiguous, and demonstrate that lineaments alone cannot be used for water-well sitting (Sander et al. 1997; Edet et al. 1998; Magowe and Carr 1999). Various explanations exist, including poor spatial accuracy of input data, large uncertainties in the cause and function of interpreted lineaments, and too few wells to be statistically significant. In addition, wells are commonly located in wide, flat areas where thick deposits of unconsolidated material obscure underlying transmissive features, which consequently go undetected in the largeextent lineament mapping. Geomorphological and hydrogeological features that imply the significance of the observed lineaments in groundwater distribution have been seldom considered in these studies. From a hydrogeological point of view, the resulting relationship is not very meaningful and explanatory without such considerations.

In this work, the relationship between borehole specific capacity and lineaments is examined in a highly fractured-karstified limestone area in northwest Vietnam. A method is proposed to uncover the relationship and to interpret the result in conjunction with geomorphological and hydrogeological features. To minimize the uncertainty associated with the spatial accuracy of lineaments, two independent lineament datasets are produced. The first is derived from a Landsat 7 ETM satellite image with a digital automatic processing technique, and the second from a stereoscopic visualization of aerial photographs at a scale of 1:33,000. The two datasets are combined in a reproducibility test to result in a unique lineament map for analysis. Lineament length and frequency density are then calculated and related to the borehole specific capacity, evaluated by sixteen pumping tests. Available data on geomorphological and hydrogeological features such as elevations of local river courses, groundwater table, boreholes, drainage density, and distance from boreholes to local river course are taken into account in the comparison. Clustering analysis is carried out on these measurements to distinguish two groups of boreholes and lineaments, and the relationship is discussed for each group. The study result shows that the geomorphological position of boreholes considerably affects the specific capacity. Boreholes drilled in a discharge area close to the valley axis show obviously higher yield than those situated on slopes and recharge areas. However, a relationship between the lineament-length density and the specific capacity is observed and is good for the second borehole group but less so for the first group. This is explained by the fact that lineaments are less detectable in discharge areas, where thick Quaternary deposits hide transmissive fractures, and the yield of the boreholes is likely influenced by recharge from the local streams. Therefore, the lineament distribution can be also considered as one of the factors that influence the borehole specific capacity.

\section{Geological and Hydrogeological Setting of the Study Area}

The study area includes $950 \mathrm{~km}^{2}$ and is located in a high mountain plateau at an elevation of 150 to $1,700 \mathrm{~m}$ a.s.l. It is characterized by a humid subtropical climate with two distinct seasons: a hot, high rainfall summer lasting from May to October, and a cool, dry winter extending from November until April. The yearly mean temperature is $21.1{ }^{\circ} \mathrm{C}$ and the mean total yearly precipitation is $1,450 \mathrm{~mm}$, about $85 \%$ of which occurs during the rainy season.

Geologically, the study area, presented in Fig. 1, lies within a regional folded basin in NW Vietnam. It is composed of three geotectonic units: the Ma River Anticlinorium Complex, the Da River Rift Zone, and the Tu Le Synclinorium Volcanic Zone. The Ma River Complex, composed of metamorphic sedimentary rocks of Proterozoic-Early Devonian age and carbonate rocks of Early-Middle Devonian age, outcrop in the west of the study area. The Da River Zone, constituting volcanic mafic and continental sedimentary rocks of Late Permian-Middle Triassic and Late Cretaceous age, and carbonate rocks of Middle Triassic age, outcrop in the centre and the Eastern part of the study area. Volcanic rocks aged Jurassic-Cretaceous of the Tu Le Zone outcrop in the northeast of the study area. The rocks are regionally 


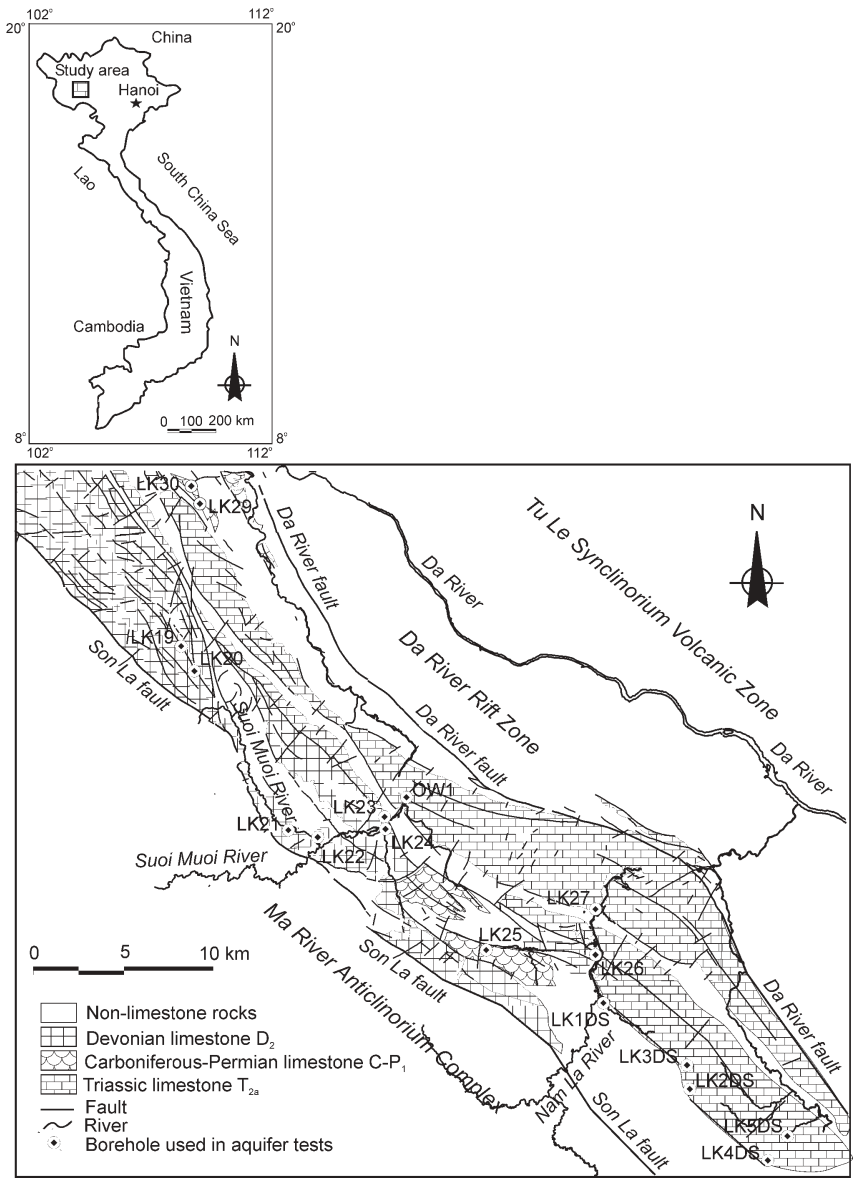

Fig. 1 Geological sketch of the study area and location of aquifer tests

NE- and SW-dipping and form local NW-SE-trending anticlines and synclines. In Fig. 1, only formations of carbonate limestone rocks are shown, while the others are grouped into non-limestone rocks and are not shown on the map. Within the area, three fault systems exist: (1) the NW-SE-striking system includes Pre-Cambrian deep faults, which control the structural geology of the region (2) the NE-SW-striking system includes younger faults that are less significant in the regional structural geology; and (3) the sub-longitudinal striking system includes the youngest faults. Based on statistical work of pumping well capacity, distribution of springs and their discharge value, Xuyen (1998) shows that the most prominent groundwater occurrences can be found along the NE-SW and sub-longitudinal-striking faults.

Carbonate rocks are strongly fractured and karstified and distributed as a 10-km-wide band (NW-SE) stretching across the study area. It is known that the limestones are much more significant in groundwater reserves in comparison with other non-limestone rocks existing in the region (Xuyen 1998; Hop 1996). The limestones belong to three stratigraphical units, each over $600 \mathrm{~m}$ in thickness: the Ban Pap Middle Devonian formation $\mathrm{D}_{2}$, the Chieng Pac Carboniferous-Early Permian Formation C- $\mathrm{P}_{1}$, and the Dong Giao Middle Triassic Formation $\mathrm{T}_{2 \mathrm{a}}$.

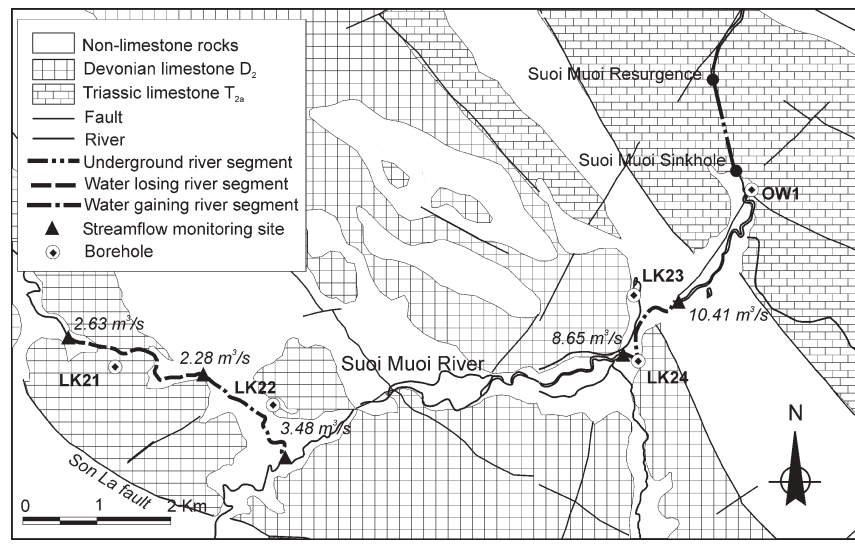

Fig. 2 Gaining and losing river segments along the Suoi Muoi River

However, no strong evidence exists whether the groundwater in the three formations is indeed hydrologically dissimilar. Therefore, in this study these stratigraphical units are considered as one karstic groundwater entity. Here, the movement of the karst groundwater is closely controlled by the regional tectonic structure. Numerous cavern conduits have been found in the region, their development coincides with the direction of geological faults and fractured zones (November 1999). The groundwater is mainly stored in fractures, crushed zones and cavern conduits and circulates with hydrodynamic conditions and the network of high hydraulic conductivity zones. It was further shown that the groundwater storage of the conduits is regionally insignificant in comparison with the storage of the rock matrix blocks and fractures. The conduits mainly play the role of conveyers between surface water bodies and the galleries collecting karst groundwater from the surrounding fractured and fissured media (Tam et al. 2001). The karst aquifer receives water mainly by regional groundwater flow, with additional, important in-situ recharge by rainfall, surface water, and water from higher lying non-karstic denuded areas. Discharge of the groundwater takes place in river valleys and depressions.

The Suoi Muoi and Nam La Rivers are two networks that drain surface water in the study area. The mean discharge of the Nam La is $5.43 \mathrm{~m}^{3} / \mathrm{s}$, and discharges up to $80 \mathrm{~m}^{3} / \mathrm{s}$ are observed during flood periods. Many sinkholes and resurgences exist along the river course creating interaction between the surface water and the karstic groundwater. Many of the sinkholes and dolines are covered with a layer of Quaternary alluvium consisting of clay, sand, gravel, and debris of host rocks. Quaternary deposits with a thickness of up to $20 \mathrm{~m}$ are also observed overlying the carbonate rocks in wide and flat valleys. In borehole OW1 in Fig. 2, situated nearby the Suoi Muoi riverbank and augured in the Quaternary deposit, no groundwater was found at a depth of $13.5 \mathrm{~m}$ below the river level. In another borehole, LK24 (Fig. 2), $50 \mathrm{~m}$ from the riverbank, the groundwater table was found $13 \mathrm{~m}$ lower than the river water level. This implies that 


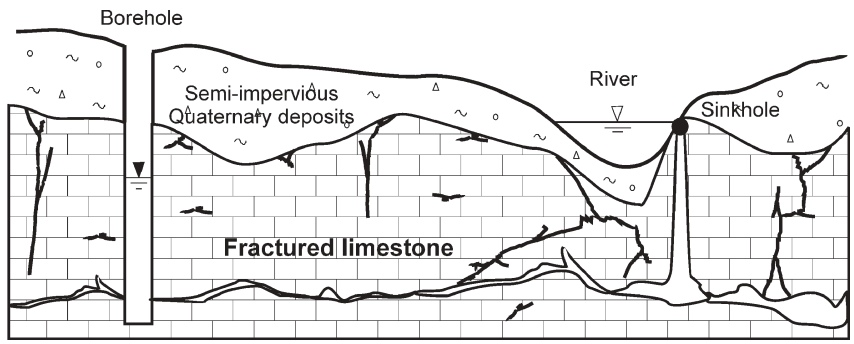

Fig. 3 Illustration of the interaction of surface water and karstic groundwater through sinkholes and resurgences along gaining and losing river segments

the overlying deposits are relatively impermeable, and the interaction of river water with karstic groundwater occurs partly through near-bank or riverbed sinkholes and resurgences, as is schematically depicted in Fig. 3. This interaction results in abrupt changes in river discharge along many river segments. A river discharge monitoring campaign was carried out during the rainy season of the year 2000; it clearly showed gaining and losing segments along the downstream part of Suoi Muoi and Nam La Rivers, which are presumably in hydraulic contact with the underlying karstic groundwater system. Figure 2 shows a part of Suoi Muoi River where such river segments were discovered. Recharge to the karstic aquifers mainly occurs through sinkholes and cavern shafts in elevated depressions and dolines; it is usually a rapid process (a couple of hours). The recharge by infiltration through the Quaternary deposits and epikarst zone is less significant, and takes a much longer time to reach the karstic groundwater system. The water table is locally and highly variable and rapidly respondes to rainstorm events. The difference in water level between the winter and summer can be up to $107 \mathrm{~m}$, as was observed in a cavern shaft $3 \mathrm{~km} \mathrm{NW}$ of LK27 (Ban Mon cave, Lagrou et al. 2001).

\section{Lineament Mapping and Lineament Analysis}

The mapping of lineament features on satellite and airborne images has been an integral part of many groundwater exploration programs in hard rock terrains. In these terrains streams, escarpments, mountain ranges, and soil tonal anomalies are often visible on remote sensing data as linear features. The common assumption in lineament mapping for groundwater exploration is that these features represent vertical zones of fracture concentration, a hypothesis that is based on early field observations of Blanchet (1957) and Lattman (1958). However, lineament mapping is somewhat subjective and the hydrologic significance of the mapped lineaments is often ambiguous. On the one hand, lineament mapping is highly uncertain, because it depends upon many factors such as quality of remote sensing data, extraction techniques, interpretation methods, and nature of the interpreted features. On the other hand, it is not easy to set up a rule of hydrological functioning of mapped lineaments for a large-extent and highly heterogeneous area. Mabee et al. (1994) and Sander et al. (1997) investigated methods for increasing confidence in lineament interpretation. The common principle of these methods is the combination of different lineament sources with additional data, such as drainage features, bedrock characteristics, and other field measurements, which results in more realistic interpretations. In a similar approach, this study produced lineament mapping from two lineament sources, which is subsequently compared with geological faults from a geological map at a scale of 1:50,000.

The first lineament source was extracted from Landsat 7 ETM imagery by two image-processing systems; the ENVI32 package (for imagery pre-processing) and the Geomatics PCI suit (for lineament extraction). The imagery is comprised of seven multi-spectral bands and one panchromatic band. The bands were pre-processed, including radiometric correction and noise reduction, to remove systematic defects and undesirable sensor effects. Various colour composites of the Landsat 7 ETM image were generated to determine the best band combinations for the interpretation of lineaments. For this purpose, principal component analysis (PCA) was carried out to maximize the use of the spectral information in the satellite data. A false colour (red-green-blue) composite of ETM bands 4, 7 and 1 was consequently selected for the lineament detection. The selected bands were contrast stretched and edge enhanced with high-pass filters to improve the detection of linear features. Directional filtering, defined on the basis of development of the regional structural geology, was also considered in the image edge-enhancement process, however this proved to be less useful. Finally, linear features were automatically extracted with the image processing system from the resulting edge-enhanced false colour composite image. The extracted lineaments were geo-referenced using an affine transformation with 37 control points, of which the coordinates were determined by differential GPS.

The second lineament source was extracted from black-and-white aerial photographs of nominal scale 1:33,000. An experienced geologist, well trained in stereoscopic techniques, captured linear features on the photographs by stereoscopic visualization. The visualized lineaments were then transferred to a computer by scanning, and then ground registered using geo-reference orthophoto method and on-screen digitizing.

In the next step, non-geological linear features were removed as much as possible from the extracted lineaments. In this process, the two lineament datasets were combined into a GIS database, where they were given a code of 1 if extracted by the automatic processing and 2 otherwise. The lineaments were also segmented, i.e. curves were split into straight lines; this was necessary since not all extracted lineaments were of true straightline form. Lineaments of less than $50 \mathrm{~m}$ in length were discarded, as they were too short and not significant in this study. The lineaments were classified into two groups; the first group consists of lineaments longer than $2 \mathrm{~km}$, and the second group of the remaining lineaments. 
The removal of non-geological linear features was consequently executed for each group. For the first group, lineaments were re-observed in both satellite image and aerial photographs, and those related to non-geological linear features, e.g. roads, riverbanks, irrigation channels, and mountain ridges, most of which having a code of 1 , were excluded from the database. For the second group, it was found that many lineaments detected by the automatic processing did not appear in the lineament dataset detected by the stereoscopic visualization; to verify if those detected by the automatic processing are truly geological linear features, a buffer zone of $100 \mathrm{~m}$ in width was constructed around each lineament coded 2; lineaments coded 1 that did not partly or fully fall within the buffer zones were re-observed on both satellite image and aerial photographs; those that were not geologically justified (e.g. did not align along negative-relief features as ravines and valleys, boundary between geological units, known faults and shear zones, straight portions of dry streambeds etc.) on either the satellite image or the aerial photographs were discarded from the database.

The step-by-step lineament extraction and processing described above provided confidence that the linear features being mapped were "really geological" because they were detected through repeated trials by several observations while geological knowledge was incorporated in the lineament detection, such that regional fractures could be justified and identified in high-resolution aerial photographs and non-geological linear features could be easily excluded from the mapped lineaments. Moreover, the combination of the two extraction methods minimized the number of missed linear features; those that had been not detected in the stereoscopic visualization were re-scanned in the automatic processing dataset and were finally justified by field observations.

Finally, a reproducibility test was carried out on the lineament database resulting in a unique dataset. The reproducibility test determined the extent to which lineament locations were reproducible. Lineament locations were considered reproducible (i.e. coincident) if (1) their azimuths were within $\pm 5^{\circ}$, and (2) the separation distance between two or more lineaments was smaller than $35 \mathrm{~m}$, the proximity of the ground registration accuracy of the remote sensing data. If two or more lineaments were considered reproducible, the location of the resulting lineament was centred between the location of the two original lineaments. Using this technique, several sub-parallel and overlapping lineaments could be easily represented by a single, coincident lineament.

Figure 4 shows a lineament scheme of the studied area where only lineaments longer than $1 \mathrm{~km}$ are included because of the small scale of presentation. A rose diagram of all mapped lineaments was also constructed (Fig. 5), which shows that a majority of the lineaments develop in NW-SE (which is also the principal direction of the regional structure) and SW-NE (i.e. a crossing of the regional structure) directions. This can be an indication of the direction of groundwater movement in the studied area.

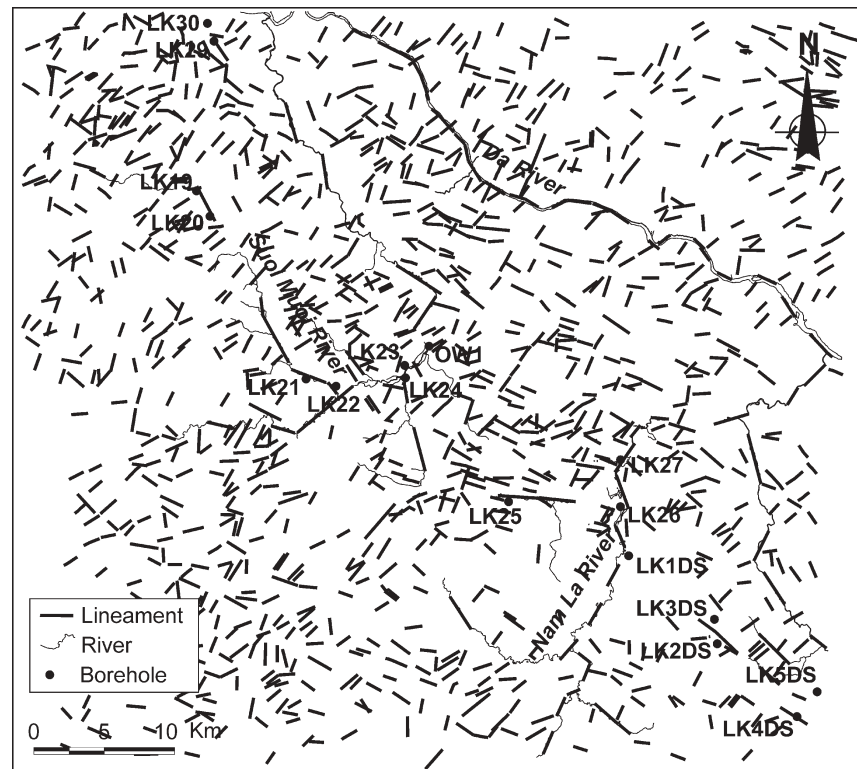

Fig. 4 Map of detected lineaments longer than $1 \mathrm{~km}$, showing location of the pumping tests and the river networks

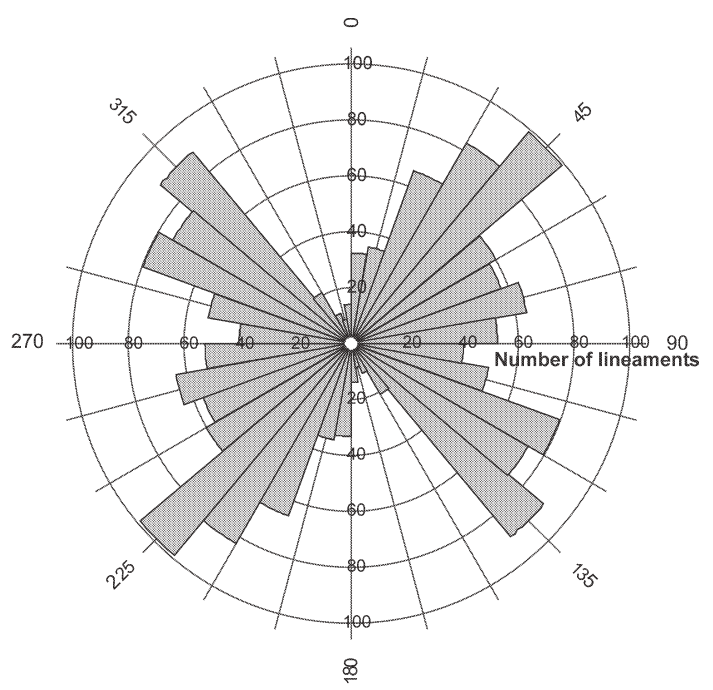

Fig. 5 Rose diagram of detected lineaments, showing two major trends (NW-SE and NE-SW) of the lineament development

For the purpose of the lineament analysis, two parameters were considered: lineament-length density $\left(L_{d}\right)$ and lineament frequency $\left(L_{f}\right)$. Lineament-length density is defined as the total length of all recorded lineaments divided by the area under consideration; and lineament frequency is defined as the number of visible lineaments per area under consideration (Greenbaum 1985). A grid of cells was constructed over the area of interest to compute these parameters. In addition, all lineaments falling into a circular neighbourhood (of radius 1.5 cell size) around each grid cell were taken into account in the computation, as is illustrated in Fig. 6. Thus, a computed value could be considered as a "representative" quantity of all lineaments falling in the cell and its neighbourhood. The computation 


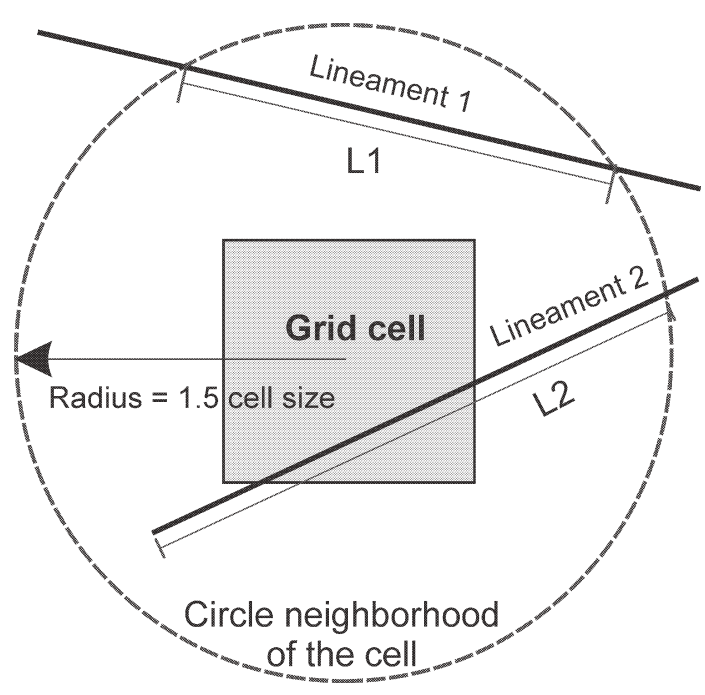

Fig. 6 Illustration of lineament-length density $L_{d}$ and lineament frequency $L_{f}$ determined with GIS ArcInfo functions: the parameters of the cell is computed as $L_{d}=(\mathrm{L} 1+\mathrm{L} 2) / \mathrm{A}$ and $L_{f}=2 / \mathrm{A}$, where A is the area of the circle

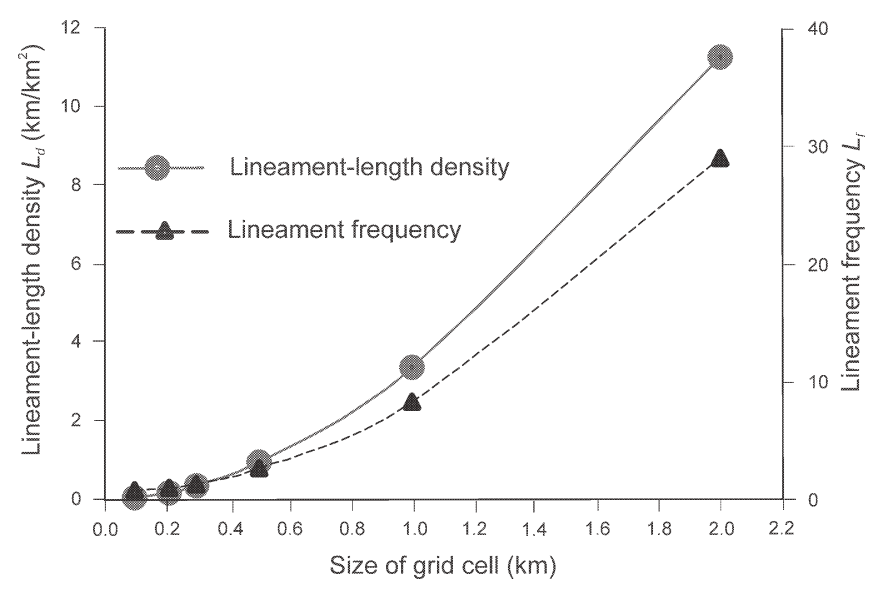

Fig. 7 Dependence of average lineament-length density $\left(\mathrm{L}_{d}\right)$ and average lineament frequency $\left(\mathrm{L}_{f}\right)$ on the grid cell-size

was carried out with the functions LINEDENSITY and LINESTATS of the GIS ArcInfo package. Often, the two parameters are correlated (Edet et al. 1998), and the correlation is cell-size dependent as will be shown in this study. Grids of cell sizes of 100, 200, 300, 500, 1,000 and 2,000 m were constructed, on which the values of $L_{d}$ and $L_{f}$ were computed. Figure 7 shows that as the grid cell size changes, the lineament frequency and the lineamentlength density exhibit a power function relationship with the cell size. The two curves intersect at a grid cell size of $300 \mathrm{~m}$. The relationship between $L_{d}$ and $L_{f}$ was investigated at the cells where the carbonate rocks are present. Correlation coefficients computed in the selected cells were plotted against the cell sizes in Fig. 8, which showed that with a grid cell size of $300 \mathrm{~m} L_{d}$ was best correlated with $L_{f}$. The good correlation implies that if a certain relationship exists between $L_{d}$ and the rock fractures, so

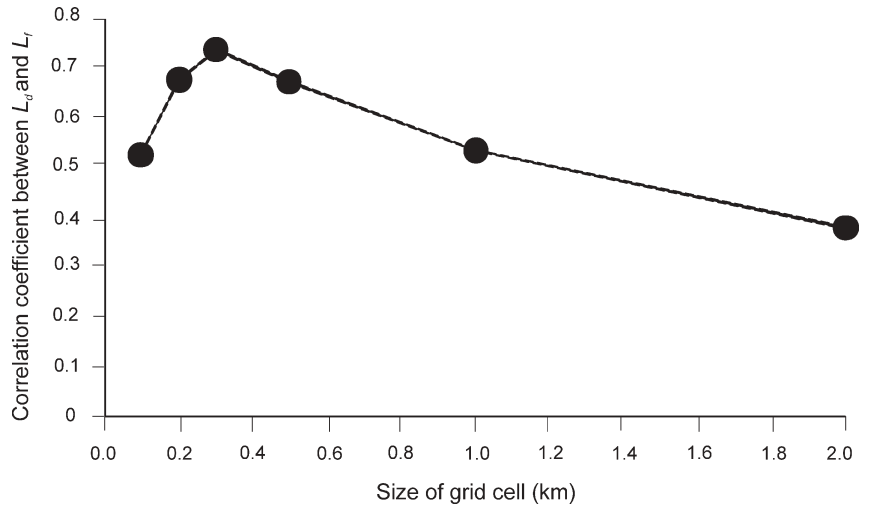

Fig. 8 Correlation coefficient between average lineament-length density $\left(\mathrm{L}_{d}\right)$ and average lineament frequency $\left(\mathrm{L}_{f}\right)$, determined for grids with cell sizes of $100,200,300,500,1,000$ and 2,000 m

does it with $L_{f}$, and vice versa. Hung et al. (2002) suggests that more parameters such as lineament-intersection frequency, i.e. the number of intersections of lineaments per unit area under investigation, can also be included in lineament analysis. However, adding more parameters requires a much more complicated analysis, which must be carried out to rate the significance of individual parameters in the lineament analysis. Hence, the lineamentlength density computed in the $300-\mathrm{m}$ cell-sized grid is considered as a representative parameter of the mapped lineaments in the study of the lineament-borehole specific capacity relationship.

To check how well the mapped lineaments reflect the structural geology, faults from a geological map of 1:50,000 scale were compared to the maps of $L_{d}$ for a small area downstream of the Nam La catchment, displayed in Fig. 9. A relatively good agreement between alignment of zones of high $L_{d}$ values and location of the faults is observed. A more detailed analysis reveals that $66.1 \%$ of the cells located within a 300-m buffer zone around the faults have a lineament-length density higher than $0.45 \mathrm{~km} / \mathrm{km}^{2}$; while $92.3 \%$ of the cells outside the fault buffer zone have a density value smaller than $0.39 \mathrm{~km} / \mathrm{km}^{2}$. Therefore, zones of high lineament-length density can be used as an indication for zones of high concentrations of fractures or faults. It should be noted that it is not possible here to define a threshold value of lineament-length density to accurately delineate zones of highly fractured rocks for a large area. Lineament distribution is not homogeneous from place to place, and is dependent upon lithological, geomorphological, and tectonic features of the site under investigation.

\section{Pumping Test Results}

In the study area, the uppermost fractured-karstified zone of the carbonate rocks is the most favourable media for the karstic groundwater to reside. The thickness of this zone is about $450 \mathrm{~m}$, an estimation based on the difference in topographic elevation between the sinkholes (approx. $580 \mathrm{~m}$ a.s.l) and the Hang Doi resurgence (136 m 
Fig. 9 Overlay of the geological faults of the Nam La catchment outlet area, digitised from a geological map, with the 300 $\mathrm{m}$ cell-sized grid of lineamentlength density
Table 1 Characteristics of the pumping tests

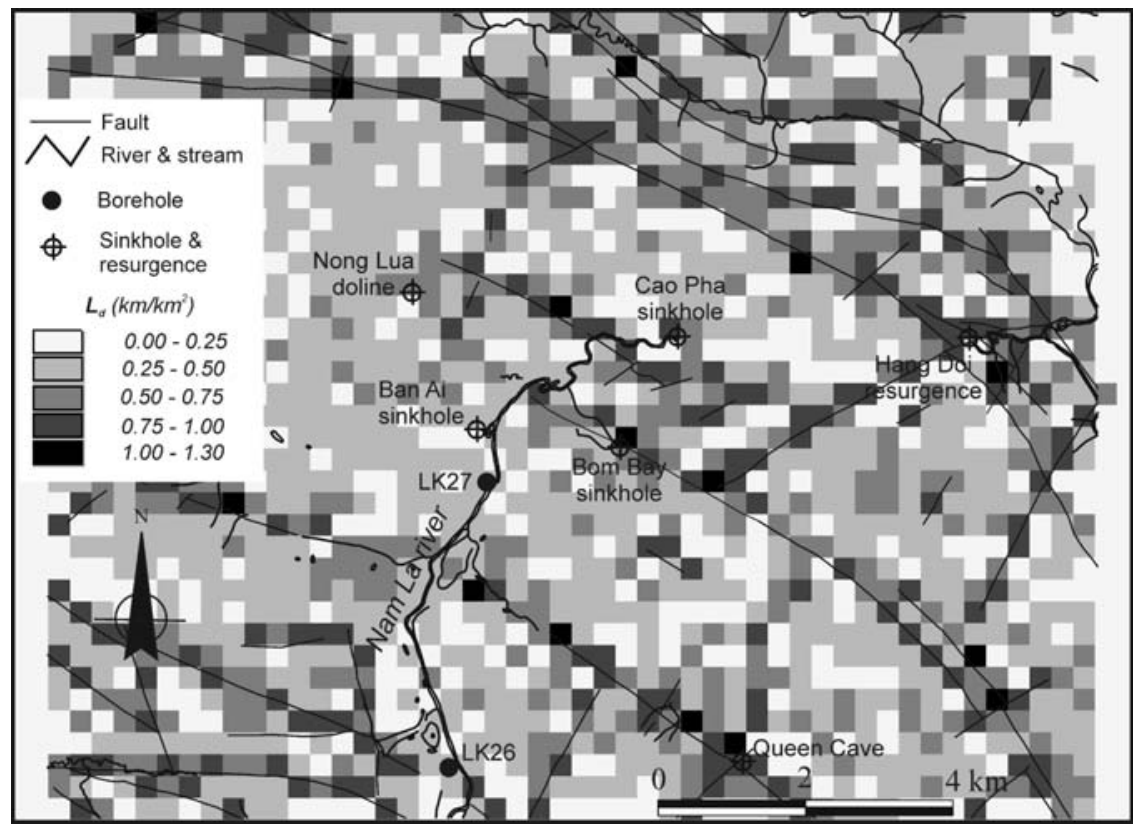

\begin{tabular}{|c|c|c|c|c|c|c|c|c|}
\hline $\begin{array}{l}\text { Borehole } \\
\text { no. }\end{array}$ & $\begin{array}{l}\text { Geological } \\
\text { formation }\end{array}$ & D (m) & $\mathrm{d}(\mathrm{m})$ & $\mathrm{H}_{0}(\mathrm{~m})$ & $\mathrm{Q}\left(\mathrm{m}^{3} / \mathrm{d}\right)$ & $\mathrm{s}(\mathrm{m})$ & $t(\min )$ & $\mathrm{Q} / \mathrm{s}\left(\mathrm{m}^{2} / \mathrm{d}\right)$ \\
\hline LK20 ${ }^{b}$ & $\mathrm{D}_{2}$ & 100.0 & 7.5 & 20.0 & 28.77 & 19.61 & 1,920 & 1.47 \\
\hline $\mathrm{LK} 19^{\mathrm{b}}$ & $\mathrm{D}_{2}$ & 100.0 & 6.9 & 20.0 & 39.74 & 22.03 & 1,920 & 1.80 \\
\hline $\mathrm{LK} 21^{\mathrm{c}}$ & $\mathrm{D}_{2}$ & 100.0 & 10.0 & 6.2 & 527.04 & 6.02 & 2,400 & 87.55 \\
\hline $\mathrm{LK} 22^{\mathrm{b}}$ & $\mathrm{D}_{2}$ & 100.0 & 8.0 & 8.3 & 559.01 & 3.94 & 2,400 & 141.88 \\
\hline LK23 ${ }^{\text {a }}$ & $\mathrm{D}_{2}$ & 70.0 & 12.8 & 8.0 & 432.00 & 1.41 & 2,340 & 306.38 \\
\hline $\mathrm{LK} 24^{\mathrm{c}}$ & $\mathrm{D}_{2}$ & 98.7 & 18.0 & 16.0 & 440.64 & 10.00 & 1,680 & 44.06 \\
\hline $\mathrm{LK} 25^{\mathrm{b}}$ & $\mathrm{C}-\mathrm{P}_{1}$ & 107.0 & 12.0 & 64.8 & 73.44 & 7.80 & 2,460 & 9.42 \\
\hline $\mathrm{LK} 26^{\mathrm{a}}$ & $\mathrm{T}_{2 \mathrm{a}}$ & 100.5 & 15.0 & 6.0 & 760.32 & 3.22 & 2,400 & 236.12 \\
\hline $\mathrm{LK} 27^{\mathrm{c}}$ & $\mathrm{T}_{2 \mathrm{a}}$ & 75.0 & 21.0 & 16.0 & 314.50 & 6.50 & 2,400 & 48.38 \\
\hline LK $29^{c}$ & $\mathrm{C}-\mathrm{P}_{1}$ & 100.0 & 4.0 & 3.5 & 191.81 & 25.30 & 2,400 & 7.58 \\
\hline LK30 b & C-P 1 & 100.0 & 0.5 & 4.5 & 43.20 & 28.03 & 2,765 & 1.54 \\
\hline $\mathrm{LK} 1 \mathrm{DS} \mathrm{S}^{\mathrm{a}}$ & $\mathrm{T}_{2 \mathrm{a}}$ & 150.0 & 10.0 & 3.0 & 445.82 & 4.80 & 2,400 & 92.88 \\
\hline $\mathrm{LK}_{2} \mathrm{DS}^{\mathrm{b}}$ & $\mathrm{T}_{2 \mathrm{a}}$ & 80.0 & 7.5 & 16.5 & 69.98 & 32.60 & 2,400 & 2.15 \\
\hline $\mathrm{LK} \mathrm{DS} \mathrm{S}^{\mathrm{c}}$ & $\mathrm{T}_{2 \mathrm{a}}$ & 75.0 & 9.0 & 4.5 & 155.52 & 26.40 & 2,400 & 5.89 \\
\hline $\mathrm{LK}_{4 \mathrm{DS}}{ }^{\mathrm{c}}$ & $\mathrm{T}_{2 \mathrm{a}}$ & 75.0 & 4.0 & 0.5 & 593.57 & 4.00 & 3,360 & 148.39 \\
\hline $\mathrm{LK} \mathrm{DS}^{\mathrm{c}}$ & $\mathrm{T}_{2 \mathrm{a}}$ & 69.0 & 3.5 & 2.5 & 421.63 & 5.74 & 2,400 & 73.46 \\
\hline
\end{tabular}

$D$ drilling depth, $d$ thickness of Quaternary deposit, $H_{O}$ initial groundwater water depth, $Q$ Pumping discharge, $s$ total drawdown, $t$ pumping duration, $Q / s$ borehole specific capacity

a confined

${ }^{\mathrm{b}}$ unconfined

${ }^{c}$ confined at the beginning but unconfined during pumping a.s.l) of the Nam La River (Fig. 9). To evaluate the groundwater reserve in this zone, sixteen pumping tests were carried out; most of them took place during the rainy season of the years 1995-1997. The tests were conducted in boreholes ranging in depth from 67 to $150 \mathrm{~m}$ where the rocks are significantly fissured and fractured. Screens and casings were only present in the sections where a collapse of the borehole walls was likely. Many of these boreholes (Fig. 1) are situated along flat valleys or main roads where access with a drilling machine was possible. A semi-impervious layer of Quaternary deposits, ranging in thickness from 0.5 to $20 \mathrm{~m}$ and overlying the carbonate rocks, was observed at the borehole sites (Fig. 3). Other characteristics of the boreholes are presented in Table 1. Be- fore each aquifer test, one or two trial pumpings were carried out to clean the boreholes and to determine the optimum pumping discharge. A gauging-bucket was used to monitor the pumping discharge and a pressure sensor to monitor the drawdown inside the boreholes. Each test included a pumping stage followed by a drawdown recovery stage, both ceased when the groundwater level observed in the pumped borehole stabilized for at least five hours (Fig. 10a). The first measurement of drawdown was often conducted $15 \mathrm{~min}$ after the pumping started, followed by 8 to 10 measurements at each half hour, and continued with hourly measurements until the end of pumping stage. The time interval between each of the first ten measurements of residual drawdown (i.e. the differ- 


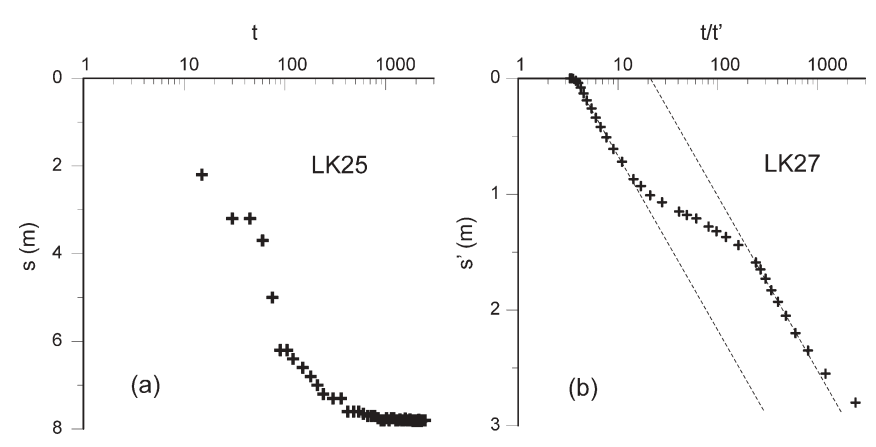

Fig. 10 Semi-log plots of drawdown (s) vs. pumping time (t) (a) and residual drawdown $\left(\mathrm{s}^{\prime}\right)$ vs. time $\left(\mathrm{t} / \mathrm{t}^{\prime}\right)$ after pumping cessation (b) of the pumping test LK27, showing double parallel line pattern often observed in fracture-rock matrix media

ence between the initial water table and the water level measured at a time after the cessation of pumping) was $1 \mathrm{~min}$. The measurement time interval was subsequently lengthened to $5,10,15$, and $30 \mathrm{~min}$, and remained at an hourly base constant until the end of the recovery stage.

As is seen in Table 1, some boreholes were initially confined and others were unconfined. Some of the confined boreholes became unconfined during the pumping as the water table dropped below the top of the aquifer. The measured drawdowns (Fig. 10) also show effects of oftenimportant borehole storage, and the presence of doubleporosity porous media, which is possibly due to karstic fractures and cavernous hollows. Figure 10b shows double parallel lines of drawdown for the recovery test LK27, which is an indication of a double porosity (i.e. fracture and rock matrix) medium (Warren and Root 1963; Kazemi et al. 1969). Moreover, drawdowns were measured inside the pumped boreholes, such that well losses must be taken into account in the estimation of the aquifer parameters. In addition, the pumping drawdown curves of some boreholes show effects of a recharge or an impermeable boundary. These boreholes are situated along a river or fault (Fig. 1), and the drawdowns are possibly influenced by these boundaries. Since there was no observation piezometer with any pumping test, it is impossible to verify this hypothesis with theoretical models. Consequently, a reliable interpretation of the aquifer parameters cannot be obtained through classical pumping test analysis methods. Hence, to avoid a large bias in the interpreted aquifer parameters, the borehole specific capacity $(\mathrm{Q} / \mathrm{s})$ is considered as a representative aquifer yield parameter to correlate to the lineamentlength density. Among many aquifer parameters, the specific capacity is a field-measured parameter with relatively little uncertainty, while others are interpreted parameters with theoretical models that depend upon the interpreter. In addition, for many bedrock aquifers this parameter has been shown to closely relate to borehole transmissivity (Banks 1992; Huntley et al. 1992; El-Naqua 1994; Mace 1997; Meier et al. 1999). Therefore, the use of specific capacity, as a measure of the water bearing capacity of the aquifer, is warranted, i.e. the measured specific capacity also represents the hydrogeological characteristics of the aquifer as the transmissivity does.

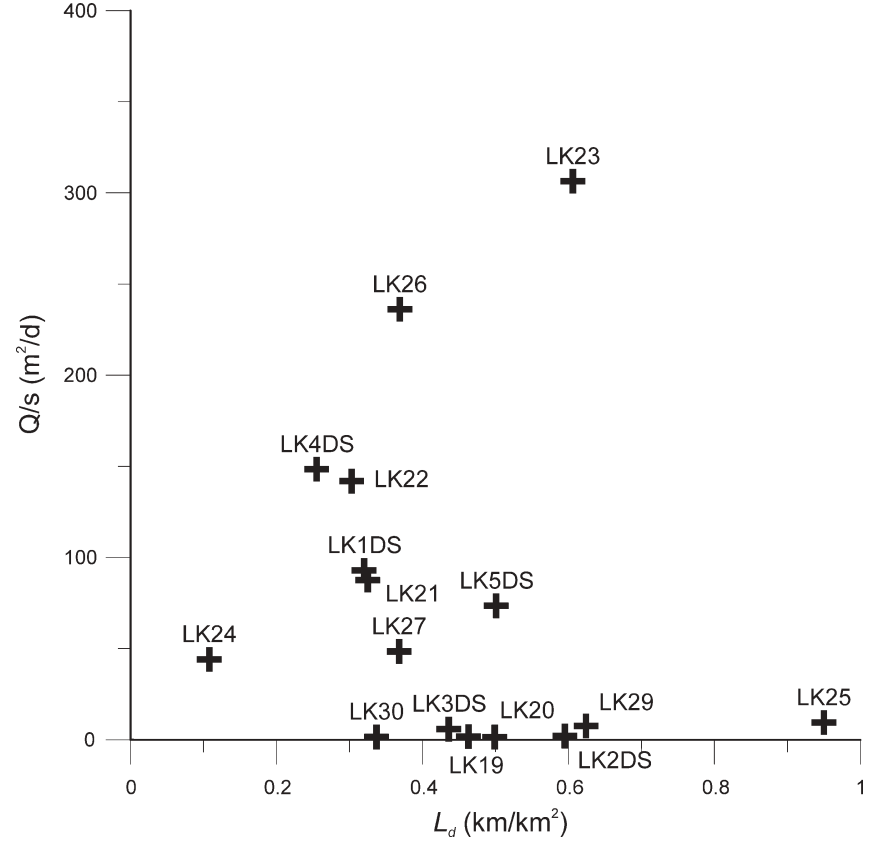

Fig. 11 Plot of specific capacity vs. lineament-length density of the borehole sites

\section{Relationship of Lineament-Length Density and Specific Capacity}

A plot of 16 data pairs of specific capacity, $Q / s$, and lineament-length density, $L_{d}$, of cells based on the location of the boreholes is shown in Fig. 11. At first look, the specific capacity does not relate well to lineament-length density at the scale of the entire study area. This comes from the fact that the study area is large and highly heterogeneous in geomorphology and hydrogeology. To enhance this relationship, the boreholes are classified into groups that are similar in geomorphological and hydrogeological features. Among the many parameters that can be included in such a classification, the following are available and could be quantified: elevation of the boreholes and groundwater table, specific capacity, elevation of local discharge area, distance to a local discharge area, lineament-length density, and drainage density. Table 2 shows the selected parameters and their values for the boreholes. In the table, elevation of the boreholes and local discharge area was measured with a differential GPS. Elevation of a local discharge area is defined here as the elevation of a point or a series of points of groundwatersurface water interaction nearest to the borehole under inspection. These points are often sinkholes or resurgences, along permanent local rivers. The gaining and losing river segments shown in Fig. 2 are examples of locations where many interaction points exist. The surface drainage density for the borehole sites was calculated with the same method and grid as was used for the computation of the lineament-length density.

A cluster analysis was performed based on the seven selected parameters to partition the sixteen boreholes into clusters, in such a way that the profiles (i.e. the selected 
Table 2 Grouping and characteristics of the 16 boreholes on basis of seven geomorphological and hydrogeological parameters

\begin{tabular}{|c|c|c|c|c|c|c|c|c|}
\hline Group & Borehole No. & E (m) & $\mathrm{H}^{0}(\mathrm{~m})$ & $\mathrm{Q} / \mathrm{s}\left(\mathrm{m}^{2} / \mathrm{d}\right)$ & $\mathrm{E}_{\mathrm{d}}(\mathrm{m})$ & $\mathrm{R}_{\mathrm{d}}(\mathrm{m})$ & $\mathrm{L}_{\mathrm{d}}\left(\mathrm{km} / \mathrm{km}^{2}\right)$ & $\mathrm{D}_{\mathrm{d}}\left(\mathrm{km} / \mathrm{km}^{2}\right)$ \\
\hline \multirow{7}{*}{ Group A } & LK20 & 744.9 & 724.9 & 1.47 & 698 & 1,726 & 0.499 & 1.45 \\
\hline & LK19 & 733.6 & 713.6 & 1.80 & 698 & 2,578 & 0.463 & 1.80 \\
\hline & LK25 & 700.7 & 635.9 & 9.42 & 636 & 1,020 & 0.950 & 9.42 \\
\hline & LK29 & 381.5 & 378.0 & 7.58 & 365 & 1,586 & 0.624 & 7.58 \\
\hline & LK30 & 358.5 & 354.0 & 1.54 & 340 & 1,201 & 0.337 & 1.54 \\
\hline & LK2DS & 704.3 & 687.8 & 2.15 & 675 & 981 & 0.595 & 2.15 \\
\hline & LK3DS & 689.6 & 685.1 & 5.89 & 675 & 865 & 0.436 & 5.89 \\
\hline \multirow[t]{9}{*}{ Group B } & LK21 & 571.2 & 565.0 & 87.55 & 565 & 231 & 0.325 & 87.55 \\
\hline & LK22 & 573.3 & 565.0 & 141.88 & 563 & 185 & 0.303 & 141.88 \\
\hline & LK23 & 521.1 & 513.1 & 306.38 & 513 & 106 & 0.606 & 306.38 \\
\hline & LK24 & 520.0 & 504.0 & 44.06 & 517 & 50 & 0.108 & 44.06 \\
\hline & LK26 & 599.6 & 593.6 & 236.12 & 593 & 281 & 0.369 & 236.12 \\
\hline & LK27 & 596.8 & 580.8 & 48.38 & 580 & 325 & 0.368 & 48.38 \\
\hline & LK1DS & 597.8 & 594.8 & 92.88 & 595 & 385 & 0.320 & 92.88 \\
\hline & LK4DS & 637.7 & 637.2 & 148.39 & 638 & 372 & 0.255 & 148.39 \\
\hline & LK5DS & 594.1 & 591.6 & 73.46 & 592 & 253 & 0.501 & 73.46 \\
\hline
\end{tabular}

$E$ borehole elevation, $H^{0}$ initial groundwater table elevation, $Q / s$ borehole specific capacity, $E_{d}$ elevation of local discharge area, $R_{d}$ distance to local discharge area, $L_{d}$ lineament-length density, $D_{d}$ drainage density

parameters) of boreholes in the same cluster are similar and the profiles of boreholes in different clusters are quite distinct. In this cluster analysis, a borehole can be intuitively thought as a point in a multidimensional space, where each dimension is represented by a parameter. Geometric (Euclidean) distance between boreholes is used as a measure to distinguish the similarity or dissimilarity between every pair of the boreholes. Because the different parameters use different units (e.g. $Q / s$ uses $\mathrm{m}^{2} / \mathrm{d}$ as a unit while the others use metre or $\mathrm{km} / \mathrm{km}^{2}$ as a unit) the data must be standardized (i.e. each standardized variable has a mean of 0 and standard deviation of 1) so that the dimensions used to compute the distances between boreholes are of comparable magnitude; otherwise, the analysis will be biased and rely most heavily on the parameter with a dimension that has the greatest range of values. Basically, the cluster analysis is performed through three steps, with the objectives to: (1) find the similarity or dissimilarity between every pair of boreholes in the dataset; (2) group the boreholes into a binary, hierarchical cluster tree (i.e. link together pairs of boreholes that are in close proximity); and (3) divide the hierarchical tree into clusters. The resulting dendrogram (Fig. 12) links the boreholes (indexed in the vertical axis) to each other at different levels (nodes) in a hierarchical tree; each level exhibits a degree of similarity between linked boreholes, which is expressed as a linkage distance on the horizontal axis. The further a linkage node is, the smaller the similarity is between the boreholes pertaining to that node. Thus, a division of the hierarchical tree into clusters (the third step of analysis) is a matter of a desired number of clusters and also a desired similarity of boreholes in respective clusters; they often are not easy to compromise. Here, a linkage distance of 2,000 is chosen, such that two clusters (the first includes LK20 to LK3DS, the second from LK21 to LK24, Fig. 12) can be distinguished. The chosen linkage distance fulfils the goal of this cluster analysis to classify groups of "as highly similar as possible" boreholes while trying to reduce the

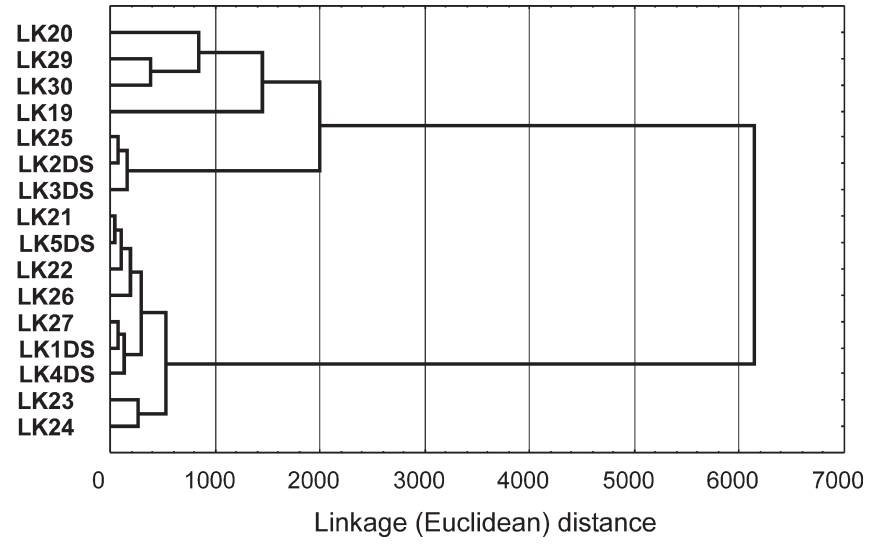

Fig. 12 Resulting hierarchical cluster tree of the boreholes, showing linkage distance (a measure to evaluate similarity between linked boreholes) of each linkage level

number of groups. Other field observations at the borehole sites (e.g. rock fracture degree, slope, and the presence of active caves near a borehole site) that could not be quantified and integrated into the cluster analysis also show a dissimilarity of the two derived borehole groups. Moreover, such a grouping reflects two distinct hydrogeological landscapes of borehole sites, i.e. those in recharge areas and those in discharge areas, similar to Krásný $(1974,1998,1999)$ who showed that boreholes in drainage areas close to the valley axis are obviously higher in specific capacity than those situated on slopes and in infiltration areas.

Group A is comprised of seven boreholes situated in small-narrow valleys with steep slopes. The soil at these locations is dry during the dry season, but becomes moistened during the rainy season, facilitating cultivation of short-life crops. Here, the water table occurs at great depth, except in a few cases, due to a high variation of groundwater levels during summer. The boreholes have a low specific capacity and are situated far from a local 


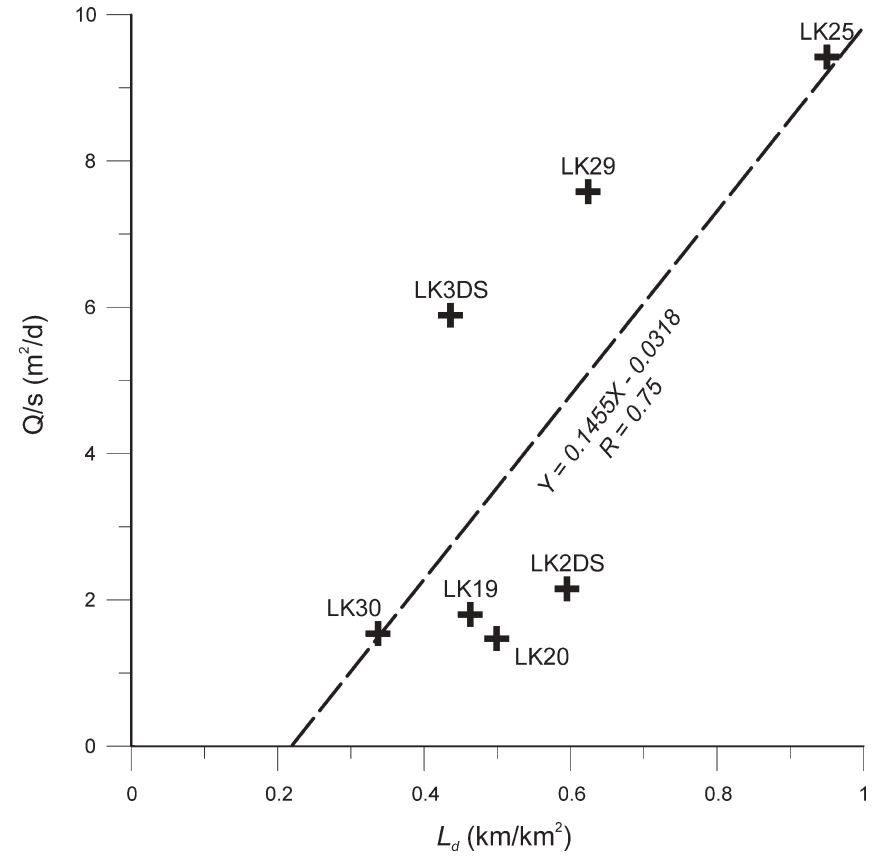

Fig. 13 Relationship between lineament-length density and specific capacity of the boreholes of group A

river network. Consequently, the drainage density computed for these borehole locations is zero. The water table observed in the boreholes is much higher than the river water level, except for borehole LK25 where the water level is more or less the same as the Nam La River. This borehole is located near an assumed sub-meridional long cavern conduit extending and discharging to Nam La river (Nam Khum cave, Dusar et al. 1994). Therefore, one can conclude that these boreholes are situated in recharge areas with respect to the river network. Because these wells are situated far from the river network, induced recharge is not possible, and their specific capacity is rather small. Consequently, the specific capacity depends only upon the local aquifer characteristics, which is revealed by a relatively good correlation between specific capacity and lineament-length density, as is shown in Fig. 13.

Group B is comprised of nine boreholes situated in river valleys with relatively flat terrains. The boreholes of this group are characterized by a much higher specific capacity compared to the specific capacity of group A. The boreholes are a short distance (less than $400 \mathrm{~m}$ ) from a river. Most of the boreholes are located along river segments, where interaction between the karstic groundwater and the surface water occurs. It is also observed that the water table in the boreholes is more or less at the same level as the river, except for borehole LK24. The karstic groundwater observed in the boreholes is therefore in hydraulic contact with the river water. Since the riverbed is isolated from the underlying limestone by a Quaternary deposit of variable thickness, the interaction likely occurs through obscured sinkholes or in zones where the Quaternary layer underneath the riverbed is relatively thin.

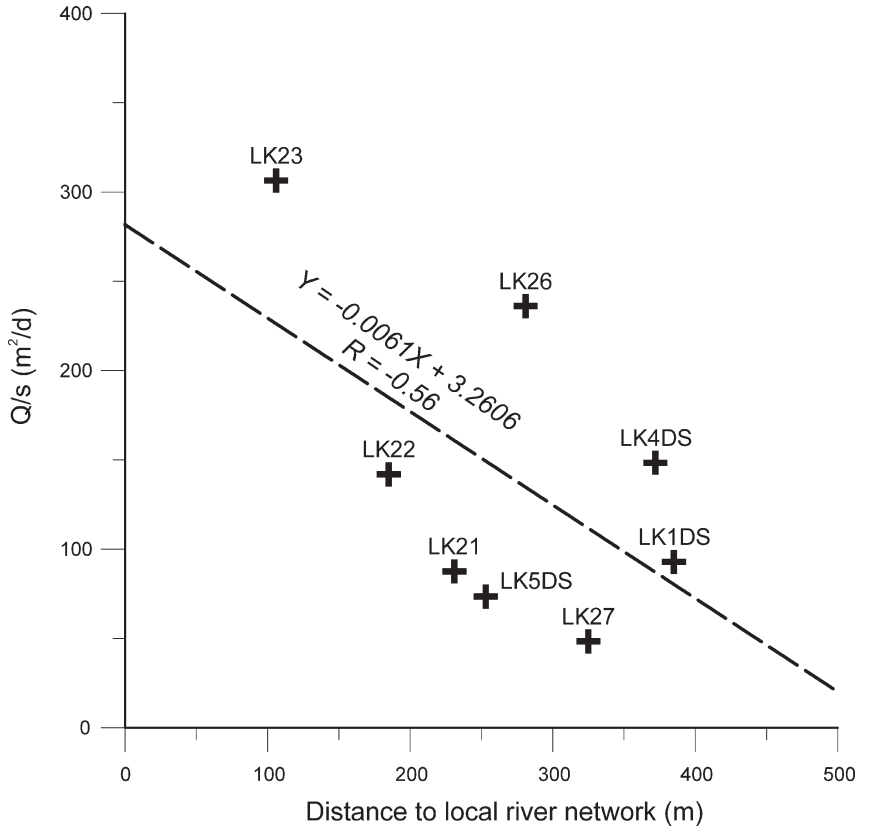

Fig. 14 Relationship between specific capacity and distance to local river network of boreholes of group B. LK24 is not included in this graph as it shows no interaction with the river water (see text)

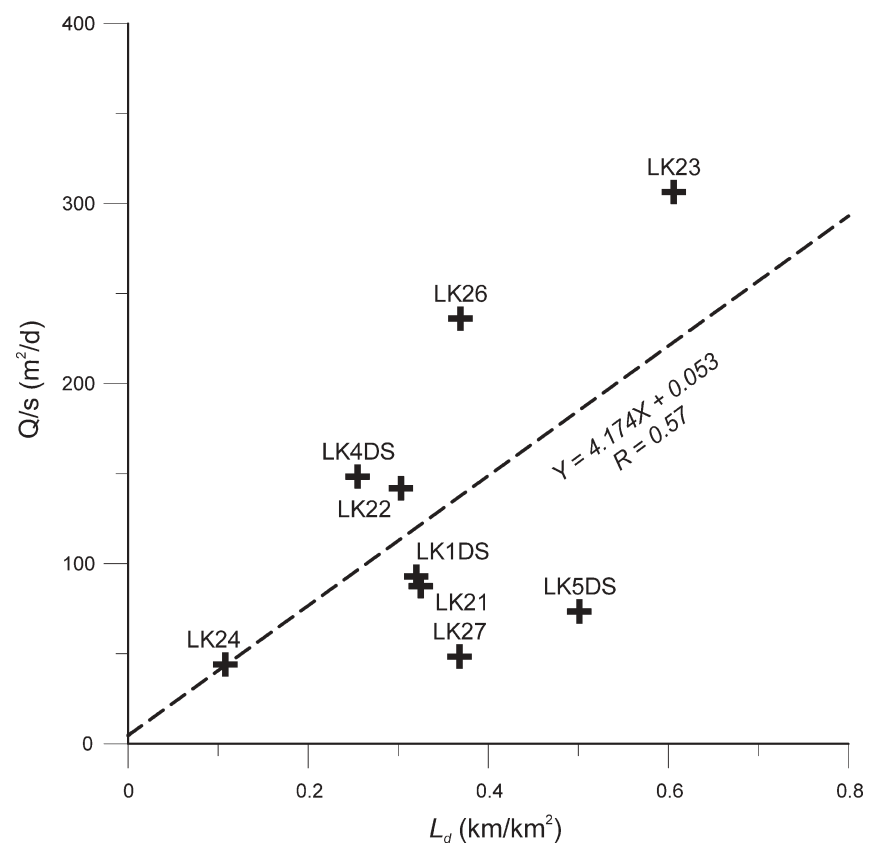

Fig. 15 Relationship between lineament-length density and specific capacity of the boreholes of group B

Where the karstic groundwater system is confined with a thick layer of impermeable materials, the interaction is unlikely to occur. That is the case for borehole LK24 where the observed groundwater level is $13 \mathrm{~m}$ lower than the nearby river water level. On the other hand, the closer the boreholes are to a river, the higher their specific capacity, as is shown in Fig. 14. All the above-mentioned 
facts imply that fractures exist in the carbonate rocks, but the Quaternary deposits cover them. This is a possible explanation of the lower lineament-length density of this group (average value for the borehole sites is $0.35 \mathrm{~km} /$ $\mathrm{km}^{2}$ ) compared to group A (averaged density is $0.56 \mathrm{~km} /$ $\mathrm{km}^{2}$ ). Consequently, the correlation between specific capacity and lineament-length density of this group, shown in Fig. 15, is lower than for group A.

\section{Discussion}

Despite the fact that pumping tests are sparse and boreholes are located in places of different geomorphological and hydrogeological conditions, this study shows that not only the borehole geomorphological position but also the lineament distribution influences the specific capacity. The former factor, considered to be more important than the later factor, is revealed by an inverse correlation between the specific capacity and the distance to the local discharge area for all boreholes, i.e. the further from the river network, the less the specific capacity of the borehole. This is also comparable to the statistical works on a few hundreds of boreholes drilled in the Bohemian Massif (Krásný 1974, 1998, 1999), which show that boreholes in drainage areas close to the valley axis are of obviously higher capacity than those on infiltration areas. In the stud-ied area, the distribution of high-capacity boreholes along gaining and losing river segments, and the observation of the same water level for river and groundwater in the boreholes, suggests a likely interaction of groundwater with surface water. Unfortunately, the influence of the local river network acting as a recharge source on the pumping drawdowns could not be fully verified by a pumping test model, due to a shortage of relevant data. On the other hand, the lineament distribution (presented in this study as the lineament-length density) can be considered as a local aquifer characteristic that influences the specific capacity. Therefore, for highland recharge areas where information of the aquifer hydraulic properties are not available, a high value of lineament distribution can be considered as an indication of high borehole specific capacity, and vice versa. For discharge areas and wide, flat valleys, this rule should be applied with great care since many transmissive zones are often blurred by an overlying layer of unconsolidated materials and therefore cannot be precisely presented in a lineament mapping.

Lineament mapping and analysis is recognised as a subjective process. Measures to minimize subjectivity, for instance based on reproducibility tests (Mabee et al. 1994; Sander et al. 1997), are often employed, and generation of coincident lineaments as described in this paper is one way of solving this problem. However, debates on lineament extraction techniques and uncertainty associated with lineament mapping continue. During the last years, several user-friendly and economically feasible imageprocessing systems have emerged, making it possible to do large-scale mapping of thousands of lineaments. Even with such automatic image-processing systems, the experience of the interpreter is still very important and decisive when field checking of mapped lineaments is limited. In this study, although the lineaments are extracted by automation processing, stereoscopic visualization and expertise on the regional structural geology verify the resulting mapped lineaments. Such a combination of automatic processing and expertise justification reduces the number of non-geological mapped lineaments, and thus, mitigates the uncertainty of interpreted lineaments.

In a study that relates lineament distribution to groundwater potential, the identification of hydrogeological significance of the mapped lineaments is crucial. Due to the high cost and time involved, it is impossible to map every lineament in a large area. However, a relationship can be determined when the lineament distribution and the aquifer tests are viewed in conjunction with their geomorphological and hydrogeological features, as is shown in this study. Those boreholes that are situated in wide, flat valleys and near a local discharge area were separated from those in narrow valleys and on steep slopes, and distant from a local discharge area. The relationship between lineament-length density and borehole specific capacity is enhanced within areas relatively homogeneous in geomorphology and hydrogeology. By clustering areas with similar geomorphological and hydrogeological properties, one implicitly distinguishes the significance of lineaments existing in these areas from others without exploring in depth what the significance is. This increases the confidence in the relationship, and allows hydrological explanations for the relationship.

\section{Conclusions}

The goal of this study was to evaluate the relationship between the borehole specific capacity and the lineament distribution for a large and hydrogeologically heterogeneous area. This goal is attained only when the observed lineaments and the boreholes are classified into two groups with distinct geomorphological and hydrogeological features. The relationship is apparent for areas of small narrow valleys with steep slopes, and less visible for areas of lowland and wide and flat valleys. This comes from the fact that many fracture zones, which are covered by Quaternary deposits in river valleys and lowlands, are not manifested in the remote sensing data. While the influence of the borehole geomorphological position on the specific capacity has been widely studied, the result of this study suggests that lineament distribution can be considered as a local characteristic of fractured aquifers. For highland recharge areas, a high density of lineaments can be considered as an indication of high borehole specific capacity, and vice versa. For river valleys and discharge areas, this deduction is not valid, as many transmissive fractured zones are often obscured by overlying unconsolidated materials and consequently go undetected in a lineament mapping. In addition, ge- 
omorphological and hydrogeological conditions must be taken into account when one tries to infer specific capacity from a lineament mapping as the influence on the specific capacity by other controlling factors, e.g. the borehole geomorphological position, can be so important that the influence of the lineament distribution is negligible or blurred.

Acknowledgements This work has been carried out within the project A3210 "Rural development in the mountain karst area of NW Vietnam by sustainable water and land management and social learning: its conditions and facilitation (VIBEKAP)" funded by the Flemish University Council (VLIR). The authors are grateful to all VIBEKAP's participants for their contributions. Special thanks are paid to Mr. Cao Xuan Xuyen (Geological Survey of Vietnam) and Dr. Koen Van Keer (former VIBEKAP coordinator) for their support in data collection of the pumping tests. Mr. Nguyen Xuan Nam is acknowledged for his contribution on building the pumping test database.

\section{References}

Banks D (1992) Estimation of apparent transmissivity from capacity testing of boreholes in bedrock aquifers. Appl Hydrogeol 4:5-19

Blanchet PH (1957) Development of fracture analysis as an exploration method. Bull Am Assoc Petrol Geol 41:1748-1759

Dusar M, Masschelein J, Tien PC and Tuyet D (1994) BelgianVietnamese Speleological expedition. Son La 1993. Belg Geol Survey Prof Pap 1994/4-No271, 60 pp

Edet AE, Okereke CS, Teme SC, Esu EO (1998) Application of remote-sensing data to groundwater exploration: a case study of the Cross River State, southeastern Nigeria. Hydrogeol J 6:394404

El-Naqua A (1994) Estimation of transmissivity from specific capacity data in fractured carbonate rock aquifer, Central Jordan. Environ Geol 23(1):73-80

Greenbaum D (1985) Review of remote sensing applications to groundwater exploration in basement and regolith. Brit Geol Surv Rep OD 85/8, 36 pp

Hop ND (1996) Report on geological mapping scaled 1:50000, Thuan Chau Area [in Vietnamese]. Research Institute of Geology and Mineral Resources of Vietnam, Hanoi, 178 pp

Hung LQ, Dinh NQ, Batelaan O, Tam VT, Lagrou D (2002) Remote sensing and GIS-based analysis of cave development in the Suoimuoi Catchment (Son La-NW Vietnam). J Cave Karst Stud 64(1):23-33

Huntley D, Nommensen R, Steffey D (1992) The use of specific capacity to assess transmissivity in fractured-rock aquifer. Ground Water 30(3):396-402
Kazemi H, Seth MS, Thomas GW (1969) The interpretation of interference tests in naturally fractured reservoirs with uniform fracture distribution. Soc Petrol Eng J (18):463-472

Krásný J (1974) Les différences de la transmissivité, statistiquement significatives, dans les zones de l'infiltration et du drainage. Mém Assoc Intl Hydrogeol 10, 1. Communications, pp 204-211

Krásný J (1998) Groundwater discharge zones: sensitive areas of surface water-groundwater interaction. In: Van Brahama J, Eckstein Y, Ongley LK, Schneider R, Moore JE (eds) Gambling with groundwater-physical, chemical, and biological aspects of aquifer stream relations. Proceeding of the 28th IAH Congress, pp 111-116

Krásný J (1999) Hard-rock hydrogeology in the Czech Republic. Hydrogéol Orléans (2):25-38

Lagrou D, Masschelein J, Philips P, Tuyet D (2001) BelgianVietnamese speleological expedition 2001. SPEKUL Speloeclub van de Universiteit te Leuven, $58 \mathrm{pp}$

Lattman LH (1958) Technique of mapping geologic fracture traces and lineaments on aerial photographs. Photogram Eng 19(4): $568-576$

Lattman LH, Parizek RR (1964) Relationship between fracture traces and the occurrence of ground water in carbonate rocks. J Hydrol 2:73-91

Mabee SB, Hardcastle KC, Wise DW (1994) A method of collecting and analyzing lineaments for regional-scale fractured bedrock aquifer studies. Ground Water 32(6):884-894

Mace RE (1997) Determination of transmissivity from specific capacity tests in a karst aquifer. Ground Water 35(5):738-742

Magowe M, Carr JR (1999) Relationship between lineaments and groundwater occurrence in Western Botswana. Ground Water 37(2):282-286

Meier PM, Carrera J, Sanchez-Vila X (1999) A numerical study on the relationship between transmissivity and specific capacity in heterogeneous aquifers. Ground Water 37(4):611-617

November J (1999) Karst geological investigation in the area of Son La and Thuan Chau (NW-Vietnam) [in Dutch]. KULeuven, Lic.-dissertation, $135 \mathrm{pp}$

Sander P, Minor TB, Chesley MM (1997) Ground-water exploration based on lineament analysis and reproducibility tests. Ground Water 35(5):888-894

Tam VT, Vu TMN, Batelaan O (2001) Hydrogeological characteristics of a karst mountainous catchment in the Northwest of Vietnam. Acta Geologica Sinica (English Edition) 75(3):260 268

Warren JE, Root PJ (1963) The behaviour of naturally fractured reservoirs. Soc Petrol Eng J (3):245-255

Xuyen CX (1998) Report on hydrogeological mapping scaled 1:200000, Dien Bien Yen Bai Area [in Vietnamese]. Geol Surv Vietnam, $202 \mathrm{pp}$ 